AL IBTIDA: JURNAL PENDIDIKAN GURU MI (2021) Vol 8 (2) : 205-221

DOI: http://dx.doi.org/10.24235/al.ibtida.snj.v8i2.9125

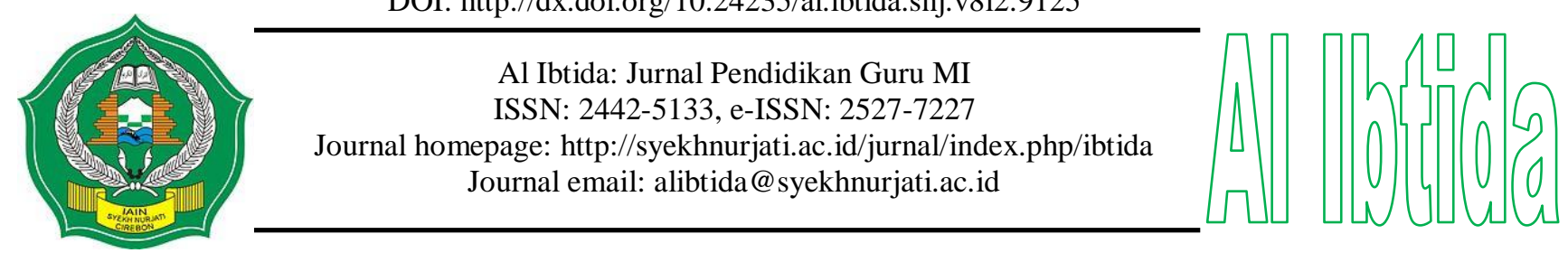

\title{
The Integration of Digital Literacy in Learning at Islamic Elementary School to Prevent the Students' Deviant Behavior
}

\author{
Susanto* \\ *Islamic Education Management Study Program, Postgraduate Program, \\ Institut Perguruan Tinggi Ilmu Al Qur'an Jakarta, Indonesia. \\ Email: susanto@ptiq.ac.id
}

Received: September $13^{\text {rd }}, 2021$. Accepted: October 23 ${ }^{\text {rd }}$, 2021. Published: October $30^{\text {th }}, 2021$.

\begin{abstract}
With rapid advances in technology and information and child attachment to digital media, integrated digital literacy in the teaching and learning process is crucial. This study aims to determine the integrated digital media literacy in the teaching and learning process developed by the Madrasah Ibtidaiyah in DKI Jakarta and its impact on the prevention of vulnerability of the students' deviant behavior. This research used a qualitative method. The sample was taken randomly. The data were collected through virtual interviews -Zoom Meeting, WhatsApp Voice Call, virtual observation, Google form questionnaires, and documentation. Then, they were analyzed descriptively. This study found that Madrasah Ibtidaiyah (MI) in DKI Jakarta has integrated digital media literacy through 4 strategies. They are the literacy of special programs, integrated to the learning material, learning sources provision, and literacy of teachers' and staff's exemplariness. The benefit of literacy to students is that they can prevent themselves from deviant behavior. It includes the ability to prevent bullying, avoid access to harmful content, and intercept cybercrime.
\end{abstract}

Keywords: integrated learning, digital literacy, deviant behavior.

\begin{abstract}
Abstrak
Seiring dengan pesatnya teknologi dan informasi serta keterikatan anak dengan media digital, integrasi literasi digital dalam pembelajaran merupakan keniscayaan. Penelitian ini bertujuan untuk mengetahui pola integrasi literasi media digital dalam pembelajaran yang dikembangkan di tingkat Madrasah Ibtidaiyah Provinsi DKI Jakarta dan dampaknya terhadap pencegahan kerentanan perilaku menyimpang pada peserta didik. Penelitian ini menggunakan metode kualitatif. Pengambilan sampel dilakukan secara acak dan teknik pengumpulan data menggunakan wawancara virtual menggunakan platform zoom, watshap voice call, observasi virtual, kuesioner melalui google form serta studi dokumen. Analisis dalam penelitian dilakukan secara deskriptif. Penelitian ini menemukan bahwa pola integrasi literasi media digital yang dikembangkan Madrasah Ibtidaiyah di Provinsi DKI Jakarta melalui 4 strategi yaitu literasi melalui program khusus, terintegrasi dalam materi pembelajaran, penyediaan sumber belajar dan literasi melalui keteladanan guru dan tenaga kependidikan. Manfaat literasi pada peserta didik mampu menumbuhkan efek cegah dari penyimpangan perilaku pada peserta didik diantaranya; mencegah bullying, menghindari akses konten negatif dan mencegah kejahatan siber.
\end{abstract}

Kata kunci: integrasi pembelajaran, literasi digital, perilaku menyimpang. 


\section{INTRODUCTION}

The development of digital media users in Indonesia is fast-growing nowadays. According to the Communications and Information Ministry of the Republic of Indonesia data, the number of internet users in Indonesia is 202 million people or $73 \%$ of the total population. Thus, Indonesia is the $4^{\text {th }}$ largest internet user in the world. Moreover, the Indonesian Internet Providers Association (APJII) nationwide survey has shown that the Indonesia's number of internet users has been raised 8.9\% from 171.2 million in 2018 to 196.7 million in the second quarter of 2020. The Indonesia's internet penetration rate has gone up to 73.7 percent from 64.8 of the 266.9 million people (APJI, 2020).

In Indonesia, there are 160 million digital users of leading platforms such as Youtube, WhatsApp, Facebook, Instagram, and Twitter (Kemp, 2020). The users of those digital media mostly are Gen Z. The survey of the Indonesian Child Protection Commission (KPAI) in 2020 revealed that children mostly use their gadget to chat with friends (52\%), to watch YouTube (52\%), to find information (50\%), social media (42\%), and others. On the other hand, children spend much of their time on digital media. Nationally, children do not use gadgets to learn 1-2 hours per day (36.5\%), 2-5 hours per day (34.8\%), more than 5 hours per day (25.4\%), and 1-4 hours per week (3.3\%) (KPAI, 2020).

The rapid growth of technology and information and the child attachment to digital media in Indonesia creates a severe problem in realizing the national education goals. According to Article 3 of Law Number 20 of 2003 concerning the National Education System, it is stated that national education has an essential role in developing capabilities and shaping character. The civilization of a dignified nation in educating the nation's life aims to develop the students' potential to become human beings who believe and fear God Almighty, have a noble character, are healthy, knowledgeable, capable, creative, independent, and become democratic and responsible citizens.

The purpose of education is substantive. The learning process is expected to allow students to be intellectually intelligent and have a noble character. In the 4.0 era, it is not easy to achieve these goals. Innovations in creating ingenious digital learning media are needed. So, they can make use of it properly and healthily. The use of digital learning media demands the creative method of digital sources and innovation in the teaching and learning process (Suleiman \& Danmuchikwali, 2020). Therefore, the integration of literacy in digital-based learning should be developed. Some experts emphasize that digital literacy promotes some positive benefits. As stated by McGuinness \& Fulton (2019),students in the UK expand their 
digital literacy as an integral part of their practical learning. It also helps them to find a job quickly after graduation.

Digital literacy is the ability to find information sources, retrieve, filter, process, interpret, and utilize offline and online digital information. It involves ICT and information literacy. On the other hand, digital literacy is defined as integrating and applying cognitive and technical abilities. It includes comprehending, using, and interpreting information. Based on the Ministry of Education and Culture in 2017, they are divided into five aspects: a) access (knowledge of the information and how to gather and obtain the information), b) manage (the ability to manage and implement the classification scheme or organization), c) integrate (the ability to interpret and describe the information (comparing, clarifying, and summarizing)), d) evaluate (the ability to decide the quality, relevance, usefulness, or efficiency of the information), and e) create (the ability to create new information through adopting, applying, designing, creating, or writing information).

Law et al. (2018) said that digital literacy is the ability to define, access, manage, integrate, communicate, evaluate, and create safe and appropriate information through digital technology and network to participate in economic and social life. It compromises some literacies, such as computers, information, data, and media literacy. In addition, Spires \& Bartlett (2012) argue that digital literacy covers three aspects: (a) finding and consuming digital content, (b) creating digital content, and (c) communicating digital content. Therefore, digital literacy is a life skill that demands the ability to use ICT and critical thinking in choosing the content and creativity to utilize it.

In contrast, the inability to utilize healthy digital media affects behavioral deviations. In their study, Dvoryanchikov et al. (2020) find that internet and social media have a negative effect that leads the children to have deviant behavior. However, Xie \& Gai (2019) argue that it can be prevented by literacy. The study shows that digital literacy can reduce the vulnerability of deviant behavior in children and adolescents. It is a serious attempt to lower the negative effect of digital media.

Goode (2016) defines deviant behavior as unorthodox traits that do not conform to the generally accepted social norms. On the other hand, Cohen (2003) argues that it is any behavior that does not adjust to the will of society or particular groups in society. Dvoryanchikov et al. (2020) said that deviant behavior fails to meet the social norms, values, and conventional rules. Others see it as unfavorable as it leads to individual maladaptation, harming both individuals and society. Besides the lack of literacy, parents also take part in it. Dullas et al. (2021) report that most deviants have dissatisfaction with their families. 
Therefore, innovative integrated digital literacy should be done simultaneously. The role of happy parenting and the control of digital media usage are also necessary.

There are some research projects conducted related to digital literacy. Yustika \& Iswati (2020) focus their research on the effect of digital media on students. It shows that the higher the students' digital literacy level, the better their academic achievement. Next, Nanda \& Budimansyah (2020) focus their research on digital media character-based through civics education. Besides, Triawang \& Kuriniawan (2021) conduct digital literacy research, which focuses on examining the effect of digital literacy levels in selecting the learning media of social science teachers.

Although this study is related to digital literacy, it has a different focus from others. This study focuses on how integrated digital literacy in the teaching-learning process and its impact on the MI students' deviant behavior in DKI Jakarta. It considers some aspects. First, it is the high child attachment to digital media in any social class. Distance learning through virtual requires them to use it more. Second, various cases of elementary school-age children also occurred in DKI Jakarta as a negative impact of unhealthy use of digital media. Third, it finds out the impact of digital media literacy on preventing susceptibility to children's deviant behavior.

\section{METHODS}

Employing a qualitative method, this study was conducted from May until June 2021. It involved the teachers and students of Madrasah Ibtidaiyah (MI) in DKI Jakarta. It was administered at two State Madrasah Ibtidaiyah (MIN) and three Private Madrasah Ibtidaiyah (MIS). Because of the Covid-19 situation, there were 20 teachers (7 female and 13 male teachers) participated. In addition, a total of 50 students were also involved in this study. They consisted of 20 female and 30 male students with the ages of 11-12 years old.

The random sampling technique was used in this study. The data were gathered through virtual interviews using Zoom Meeting, WhatsApp Voice Call, virtual observation, Google form questionnaire, and documentation. The researcher's interviews were related to the concept of digital literacy, literacy activities, the reason for applying literacy, the goals of literacy, and the effect of literacy on students. This study used the descriptive analysis method. Although depicting and analyzing the results of the research, it was not used to make broader conclusions (Sugiyono, 2011). It was depicted and presented in graphs and narrative descriptions. 


\section{RESULTS AND DISCUSSION}

\section{Integrated Digital Literacy in Learning}

Based on the interviews, virtual observation, and documentation, the researcher found that the integrated digital media developed by MI in DKI Jakarta had four strategies. They were digital literacy through special programs, integrated digital literacy in learning materials, digital literacy through the provision of learning resources, and literacy through the estimableness of teachers and the staff.

According to the interview and documentation, there were some reasons behind the strategy. First, the students' digital literacy could not be done by a single method, but it needed varied methods. Second, the elementary students' literacy was not effective in shortterm programs. It required a simultaneous integration between literacy and the teachinglearning process and the supportive learning sources. Third, for the perfection of the literacy process, it demanded an exemplariness of the teachers and staff. The students were in an imitating phase so that they would imitate their teachers. Fourth, the integration of digital literacy was essential in the implementation of the 2013 curriculum. It required the students to explore knowledge using digital media.

In detail, the results of the questionnaire related to the role of Madrasah Ibtidaiyah (MI) in DKI Jakarta are as follows.

1. Digital Literacy through Special Programs

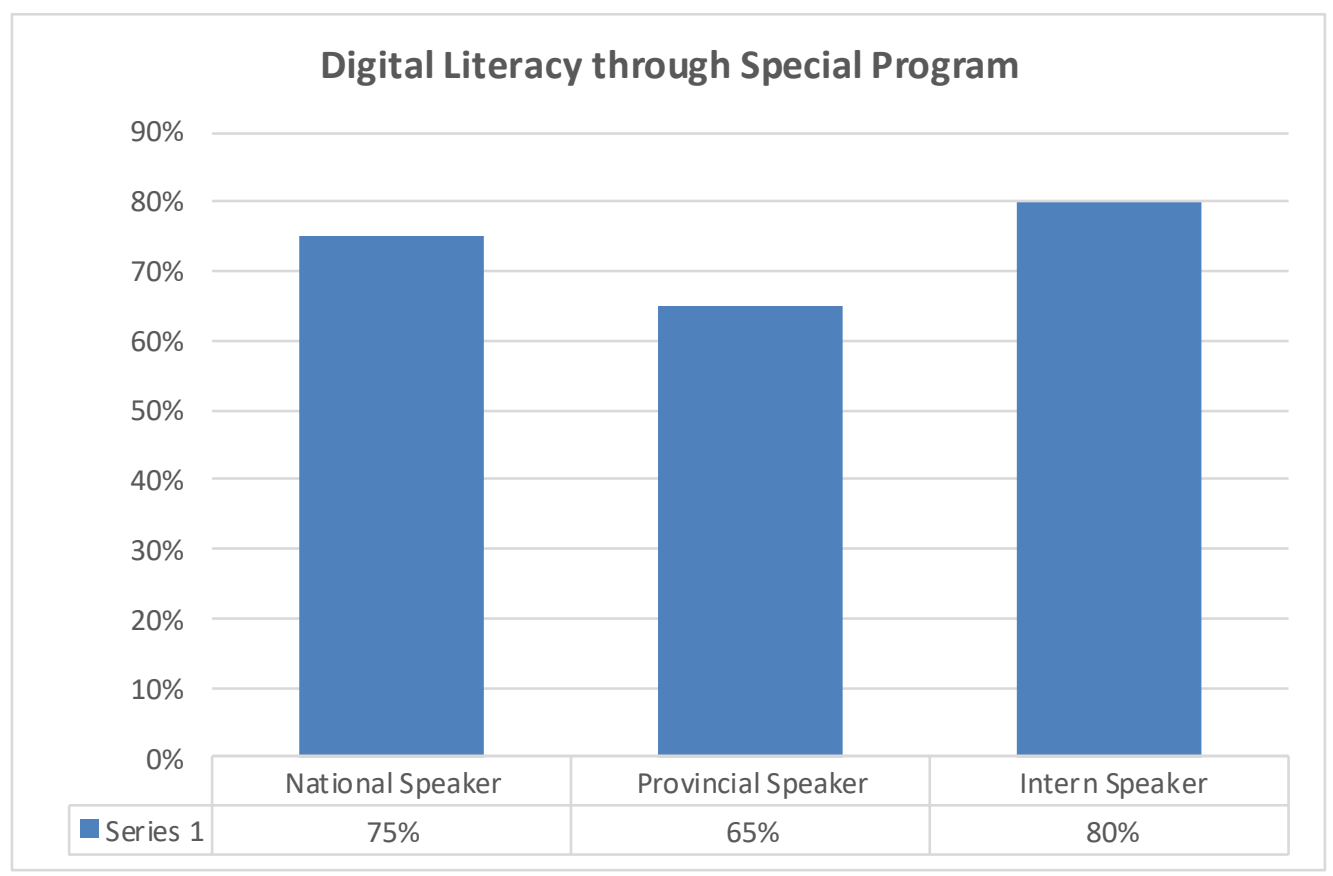

Graph 1. Digital Literacy through Special Program 
Graph 1. shows that to develop the students' digital literacy, Madrasah Ibtidaiyah in DKI Jakarta creates special programs, such as seminars/counseling and socialization on the importance of health and proper digital media utilization. It involves national speakers, provincial speakers, and internal speakers. Based on the findings, the involvement of the national speaker is $75 \%$, the provincial speaker is $65 \%$, and the intern is $80 \%$. It shows the adherence to madrasa digital literacy in DKI Jakarta.

2. Digital Literacy through Integrated Learning

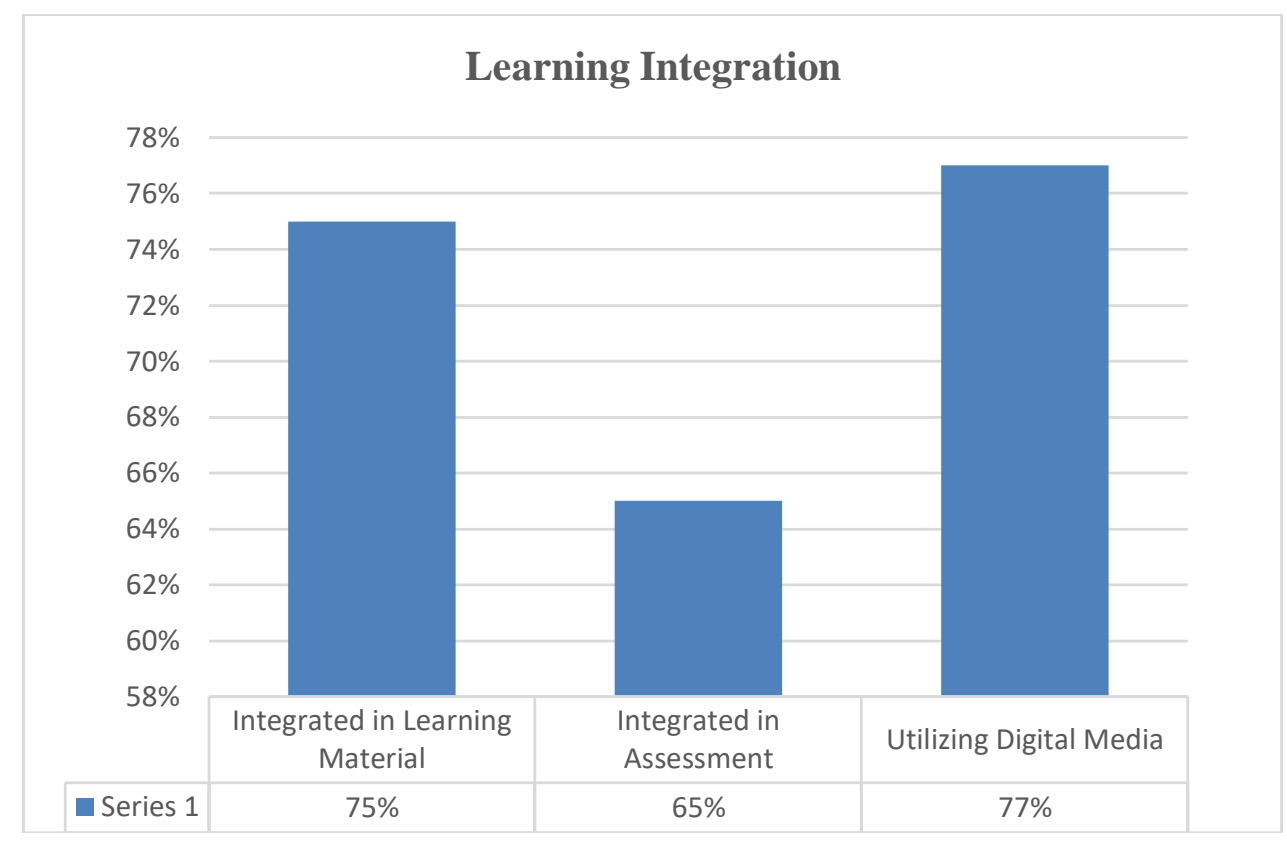

Graph 2. Integrated Learning Program

According to Graph 2, digital literacy is implemented in integrated learning. The teachers' use of a digital literacy through integrated in learning material was $75 \%$. It is by inserting literacy in the material or sub-discussion of the relevant subject, including giving examples of relevant material. In addition, $65 \%$ of teachers employ digital literacy when giving assignments to students, both in class and as home works. Teachers also do it through habituation literacy in the use of digital media $(77 \%)$. 
3. Digital Literacy through Provision of Learning Resources

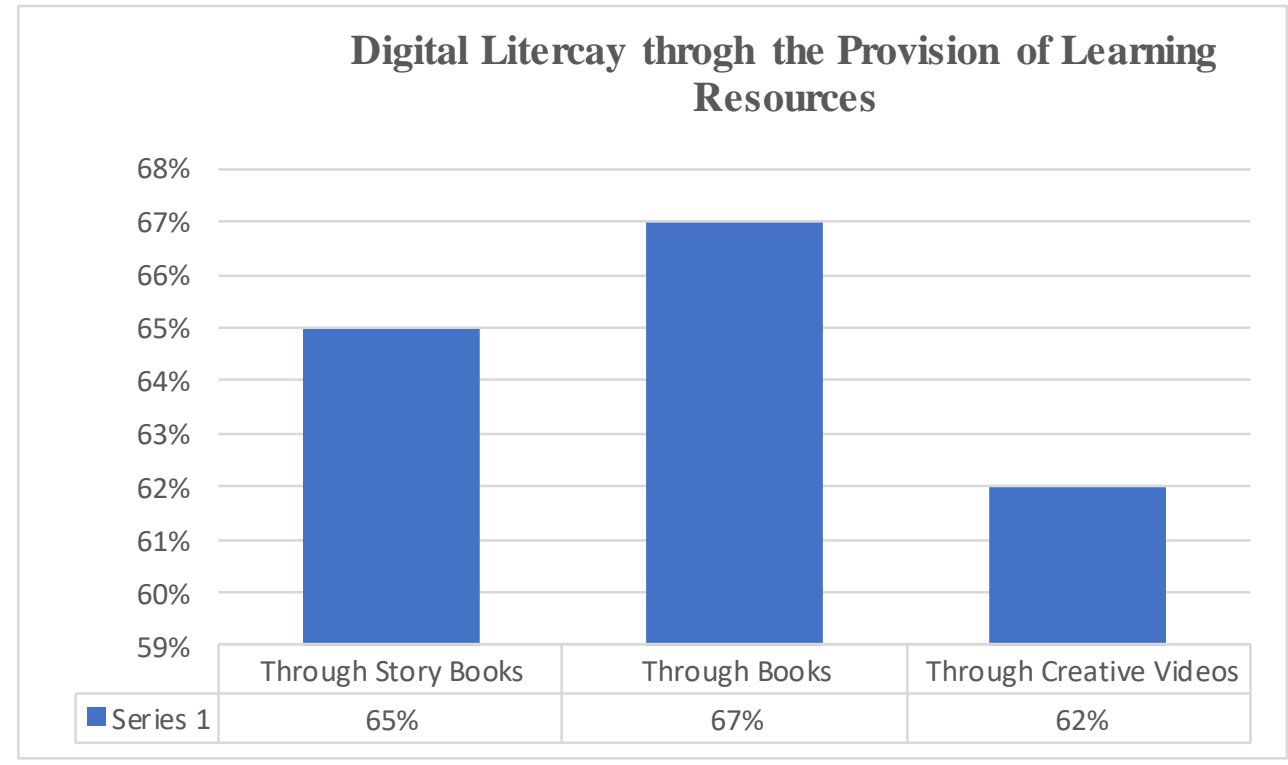

Graph 3. Digital Literacy through Provision of Learning Sources

Based on Graph 3, digital literacy is implemented through learning resources in the library of Madrasah Ibtidaiyah. The learning resources include literacy in various strategies. They are the provision of storybooks, books, and creative videos. The study found that $65 \%$ of MI teachers in DKI Jakarta carried out literacy through the provision of storybooks, then through books (67\%), and the provision of creative videos containing digital literacy messages $(62 \%)$.

4. Digital Literacy through Exemplariness

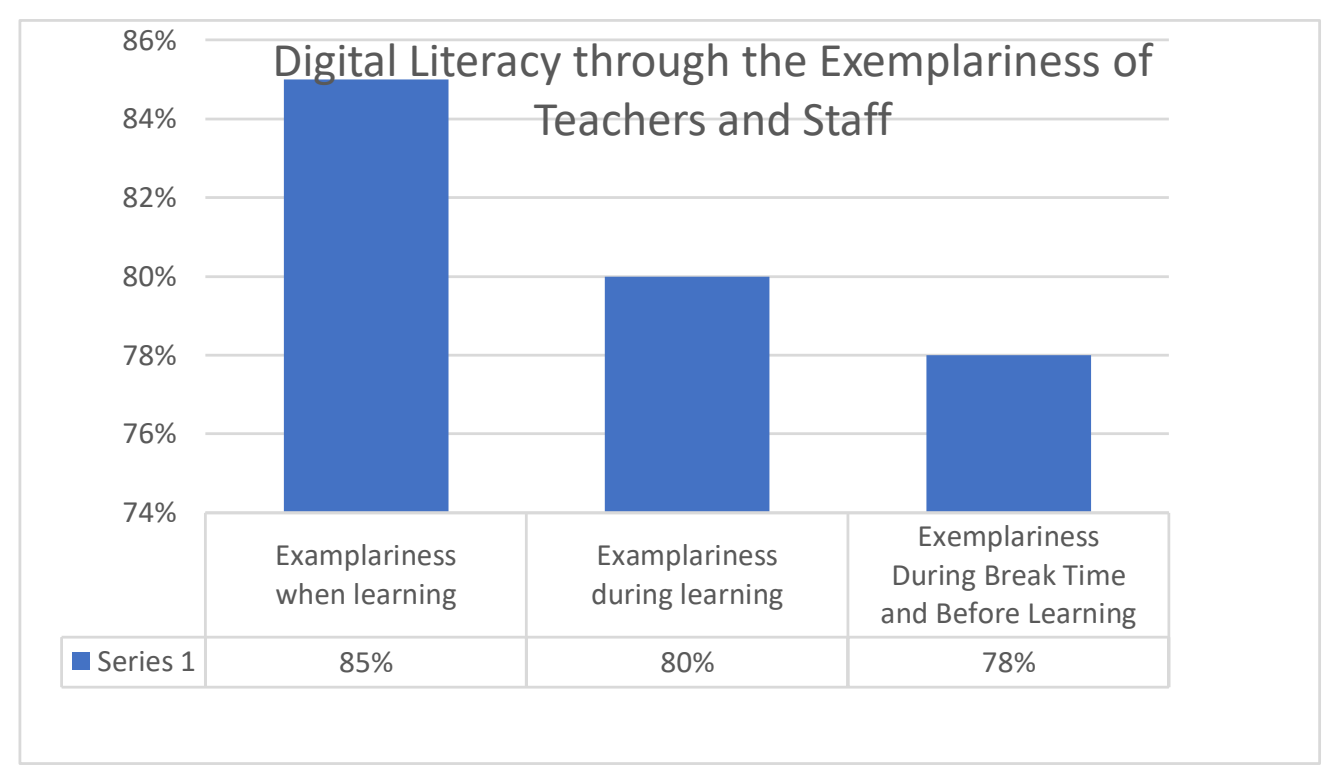

Graph 4. Digital Literacy through the Exemplariness of Teachers and Staff

Based on Graph 4, the digital literacy program is implemented through the examples of teachers and staff in the education unit. Exemplary habituation is consistently done through 
the exemplary teaching-learning process when learning (85\%), during learning (80\%), and during the break times and before the teaching-learning process (78\%).

\section{Benefits of Digital Literacy in Preventing Deviant Behaviour}

Various factors can cause the children's vulnerability to deviant behavior. The accessibility and use of digital media becomes a new challenge in digital media today. According to the Indonesian Child Protection Commission (KPAI), the dominant factor causing children to be exposed to deviant behavior is the inability to use digital media healthily and appropriately.

Based on the research findings, the benefits of digital literacy for students include; the proper utilization in the use of digital media, protection in the use of digital media, and preventing potential deviant behavior of children.

a. The Aspect of Digital Media Utilization

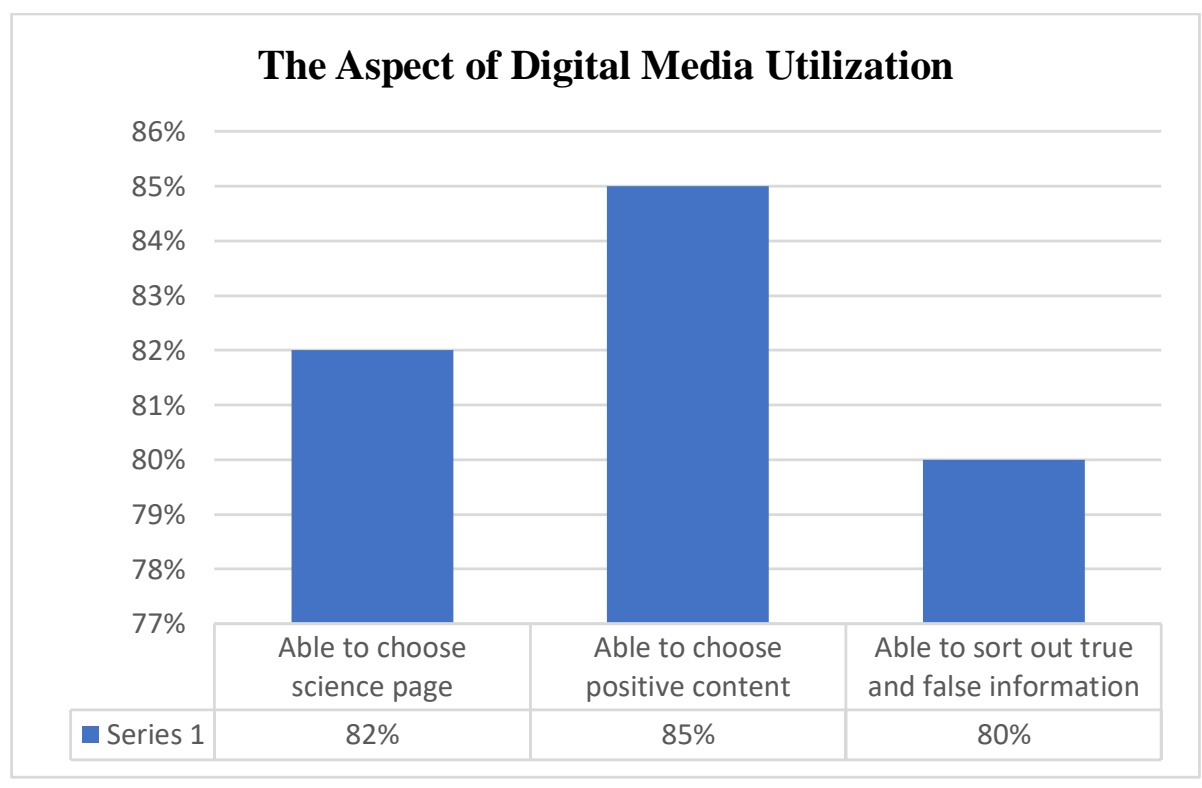

Graph 5.The Aspect of Digital Media Utilization

According to Graph 5, after apprehending literacy in using digital media, the students can choose knowledge content pages (85\%). They also can filter the true and false information $(80 \%)$. 
b. The Aspect of Protection in Utilizing Digital Media

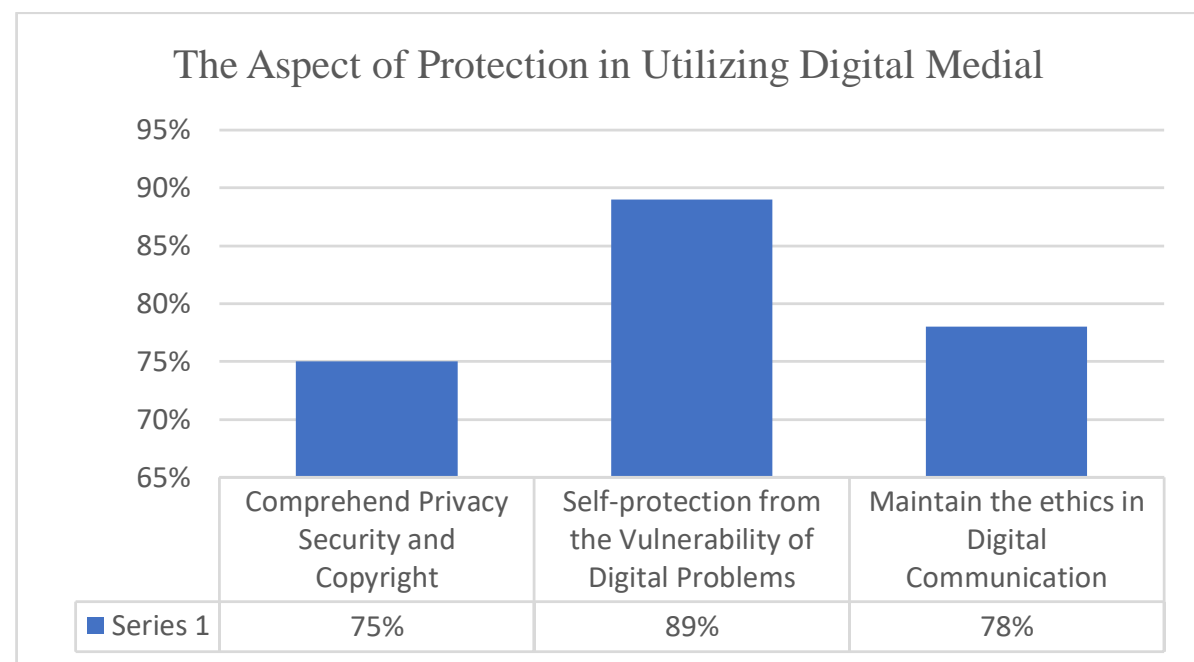

Graph 6. The Aspect of Protection in Utilizing Digital Media

Based on Graph 6, after the students learn about digital literacy from the teacher, they can understand the security of personal data and copyright (75\%), and then $89 \%$ of the students can protect themselves from digital problem vulnerabilities whereas $78 \%$ of the students can maintain digital communication ethics.

c. The Aspect of Awareness in Preventing Bullying

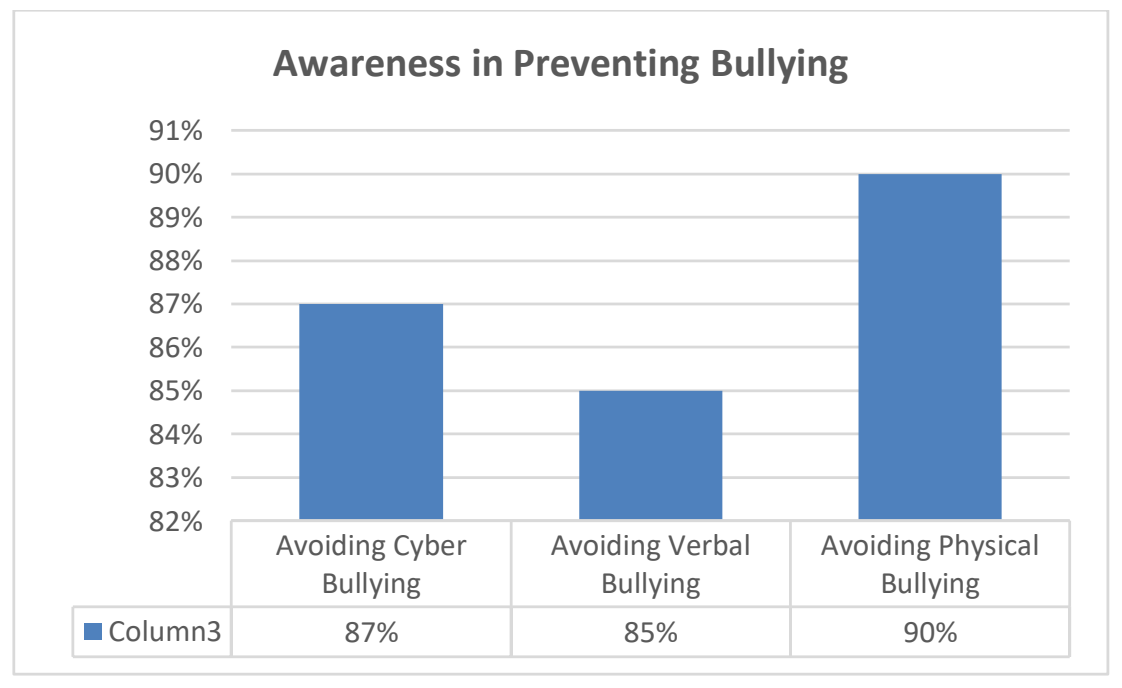

Graph 7. Awareness in Preventing Bullying

Based on Graph 7, the impact of digital literacy on the growth of children's awareness of avoiding bullying behavior at a child's age is quite good. After getting an exposure of digital literacy from the teacher, students showed good behavior, namely avoiding cyberbullying (87\%), avoiding verbal bullying (85\%), and avoiding physical bullying (90\%). 
According to those percentages, awareness of avoiding various forms of bullying can be prevented through literacy continuously.

d. The Aspect of Awareness in Avoiding Negative Content

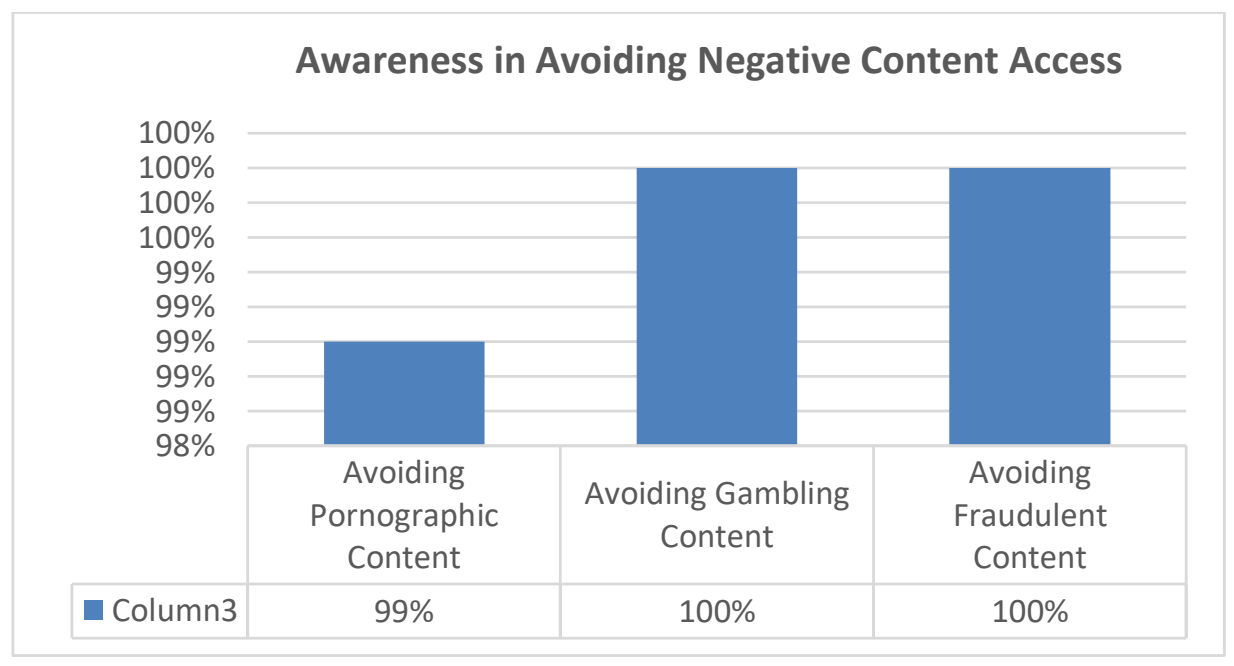

Graph 8. Awareness in Avoiding Negative Content Access

Graph 8 shows that digital literacy has positive benefits in preventing children from being exposed to deviant behavior such as accessing to negative content, pornographic content, gambling content, and fraudulent content. After the children learn digital literacy, the results show that they can avoid access to pornographic content (99\%) independently, avoid gambling content (100\%), and avoid fraudulent content (100\%). These data show the success, and preventative effects of literacy efforts carried out in education services.

e. Awareness in Avoiding Cybercrime

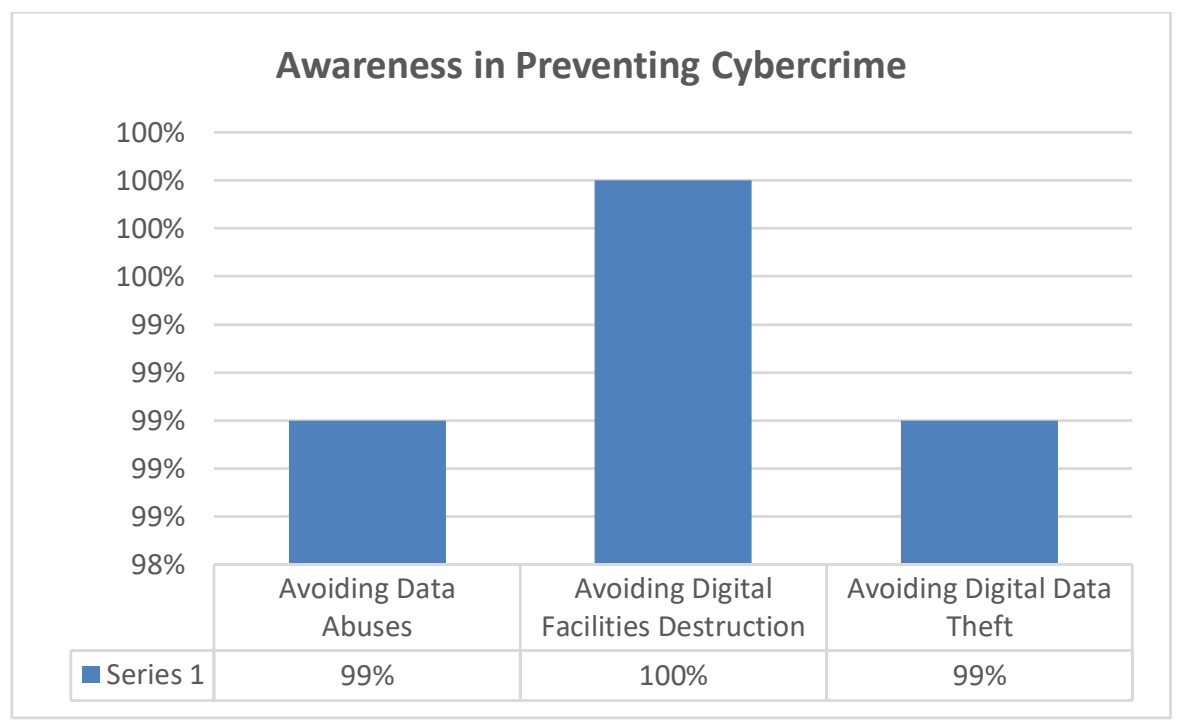

Graph 9. Awareness in Avoiding Cyber Crime 
Based on Graph 9, digital literacy efforts positively impact on raising children's awareness to avoid cybercrime. Today's cybercrime has become a new vulnerability for children who are attached to digital media. The results show that after a child gets a digital literacy program, they can avoid data abuse (99\%), then avoid destruction of digital facilities (100\%), and avoid digital data theft (99\%). This portrait shows that digital literacy provides excellent leverage for preventing children from being vulnerable to being involved in cybercrimes.

Based on the findings, the students' digital literacy has positive benefits in using, protecting, and preventing deviant behavior of elementary school students. After apprehending literacy in digital media, $82 \%$ of students are able to choose science pages well, choose positive content (85\%), and filter the true and false information (80\%). Thus, it indicates the success of integrated digital media learning innovation.

On the other hand, students who learn digital literacy from the teachers can protect themselves from digital problems (89\%). Even they attach to digital media; they are vulnerable to the effect of less literacy knowledge. The benefit is that the digital literacy impact to the students' awareness to avoid child's bullying and other deviant behaviors. Based on the findings, after the teachers equip them with digital literacy, $87 \%$ of the students avoid verbal bullying, and $90 \%$ avoid physical bullying. Besides, $99 \%$ of the students can avoid access to pornographic content independently, $100 \%$ of them can avoid gambling content, fraudulent content, and cybercrime. It shows the success of digital literacy in education services.

The positive impact of digital literacy to prevent children from deviant behavior as the research findings is in line with the research findings of Xie \& Gai (2019). They said that literacy media programs have succeeded in reducing deviant behavior. Thus, literacy education is needed for the development of children and adolescents. Besides, it is relevant to the research conducted by Fardiah (2021). She said that adolescents who have adequate digital literacy defenses could anticipate adverse risks and can control themselves.

The massive effect of the Covid-19 pandemic and the rapid growth of technology has changed people's behavior, even the education system. The higher they attach to digital media, it demands an urge for integrated literacy. It is part of the strategy to improve the quality of education based on the Programme for International Student Assessment (PISA). It generates qualified human resources (Kurniawan \& Eza, 2019). Moreover, digital literacy skills are the basic need to face the today's technological rapidness. 
The Covid-19 pandemic has forced rapid transformation into 4.0, and digital use is inevitable. The conventional learning model has changed quickly into distance learning, which relies on information and communication technology media support. To support practical learning amid the Covid-19 pandemic, it needs the role of teacher, literacy, and parents to assist it. They participate in giving literacy and providing the full support of distance learning virtual-based (Mulyana, 2020).

The rapid of students' access to digital media has two consequences - positive and negative. So, the Indonesian generation have to be the smart digital user (Afwiyana, 2019; Irianto \& Febrianti, 2017). By utilizing digital media intelligently, the digitization of learning services can be adequately managed and foster a healthy digital ecosystem. The rapid development of information technology requires all elements of education, including students, to have basic skills related to digital concepts. However, literacy integrated learning will not be realized without qualified teachers. Hence, the teacher's quality must be ensured to create integrated digital literacy.

In the today's digital era, teachers must be adaptive to technological developments (Astini, 2019). Consequently, teachers are required to play their role effectively as learning facilitators (Olson \& Stalbrant, 2008). In virtual-based learning, the teacher gradually introduces digital devices or media to students by introducing technological devices as learning media. The teacher's strategy in providing digital literacy goes through some stages of literacy strategies in learning, namely the initial stage, implementation, planting, and creating positive change. In addition, teachers must also provide examples of digital use. It is because exemplary is a vital pillar of successful literacy (Fitriadi, 2013). With good knowledge and example, digitally literate students will know how, why, and when to use digital tools appropriately. Students can also see opportunities in utilizing digital technology, expressing creative ideas, reviewing information, and thinking critically (Anggeraini et al., 2019). With the hope that if students can explore technological literacy, they can create knowledge creation to create positively. There are three primary keys in the UNESCO ICT competency Framework for Teachers: literacy technology, knowledge deepening, and knowledge creation (Butcher et al., 2014).

Not only Indonesia but also all countries affected by Covid-19 also require education to adjust distance learning, including the demands of learning innovations. In this case, the competence of teachers is very decisive, along with the Covid-19 situation, which is attached to digital media, the success of digital-based learning does not depend on the availability of digital devices, but on the competence of teachers in its application (Jannah et al., 2020). So, 
digital literacy is not just a person's ability to operate a computer device but the extent to which one can creatively use it (Jacobs \& Castek, 2018).

Technology is like a double-edged sword. If appropriately used, it can have positive and valuable impacts, but it will negatively impact if not used wisely. Various studies have shown that excessive use of gadgets to access technology could harm children at school age. Milana, in her research, stated that access to digital media is a severe challenge to the children's growth and development. Many negative impacts are caused such as affecting children's health problems that can impact to their development, making them prone to crime, affecting the children's behavior, making them difficult to concentrate on the real world, impairing brain function in children (Pre Frontal Cortex), and can be dependent on gadgets. Parents' role is crucial to supervise, control, and pay attention to their children's activities for better development (Subarkah, 2019).

Syifa \& Setianingsih (2019), in their research stated that ten children in class V (five) who used gadgets with a duration of more than 2 hours per day experienced behavioral changes. The negative impact of gadgets affects the psychological development of children, especially on the aspects of emotional growth and moral development. In emotional growth, those who use gadgets become irritable and rebellious, imitate behavior in gadgets, and talk to themselves on gadgets. While in terms of moral development, it impacts their discipline, children become lazy to do anything, leave their obligations to worship, and reduce learning time due to playing games and watching YouTube too often.

The rapid development of information technology in Indonesia can affect social life and public security. The use of the internet in its development does not fit the original purpose of this technology being developed, meaning that its use is not always for positive activities. On the contrary, it is prone to causing behavioral deviations, including violations of the law. Positive use means utilizing technology for social progress and development. Still, the inappropriate use of digital media could weaken and even destroy social joints and social order (Suroso, 2017).

The high penetration of internet users opens up opportunities for the emergence of various cybercrimes. Cybercrime is a criminal act that violates the law by using computer technology as a crime tool. Cybercrime occurs because of advances in computer technology or the ICT, especially internet media (Napitupulu, 2017). The Indonesian Child Protection Commission as an independent state institution, in the last 3 (three) years, noted that cybercrimes are increasingly rampant; even complaints related to cybercrimes are also increasing (KPAI, 2020). 
Children are at risk of becoming victims of crime in cyberspace; even in many cases, they are also involved as perpetrators. Cases of data theft, economic crime, child trafficking, online exploitation, pornography business are not a few through cyber doors. This condition requires literacy so that children are capable of using digital media. The role of teachers and parents is required to provide education and control over children in using information technology so that its use is measurable and efficient. Moreover, nowadays, children in Indonesia are very vulnerable to being exposed to pornography and becoming objects of sexual exploitation in cyberspace (Atem, 2016). Cyber security education for children is essential to avoid the potential risks faced as users and when communicating through virtual media. However, it is realized that this effort is still facing some challenges and obstacles, including; the levels of teacher knowledge, literacy and teacher knowledge levels, financial support, and resources (Rahman et al., 2020). Thus, integrated digital media literacy in learning needs to be carried out in a planned, systematic, evaluated, and sustainable manner so that children's futures can be well protected.

Therefore, efforts are needed to foster resilience in using digital media or what is commonly known as digital media online resilience to prevent children from being exposed to deviant behavior. Resilience means spring power, springy power, or joy (Echols \& Shadily, 2013). According to Przybylski et al. (2014), online resilience is viewed as an individual's ability to adapt to the online world's changing and sometimes stressful environment and feel empowered to act rather than react in the face of new threatening challenges. Thus, with this ability, individuals will be more empowered in filtering and responding to various things they encounter when interacting with digital technology. With the breadth of learning opportunities for children and all the readily available information, the risk vulnerabilities of the digital world need to be addressed and prevented as early as possible through efforts to foster resilience in cyberspace. Equipping children with the ability to independently assess and sort out various influences from the online world is a fundamental step that needs to be pursued. Growing online resilience in children is a critical need to strengthen their ability to manage various risks to develop into solid individuals (Hendriani, 2017).

Moreover, the virtual world seems to be a free market. All content that can cause deviant behavior is quite diverse and continues to grow in various new modes. Sadism, pornography, gambling, trafficking, fraud content are easy to find and access for students of the age group. Thus, the ability to independently assess and choose various influences from the online world is vital for individuals to master from elementary school age. With this provision, children have enough ability to distinguish responses to positively charged content 
from negative ones. Children will have an excellent ability to respond to various risk factors in the digital world. Building online resilience in children today is significant in strengthening their ability to manage various risks. Besides, it reduces children's access to harmful online content (Hendriani, 2018).

\section{CONCLUSION}

Overall, Madrasah Ibtidaiyah in DKI Jakarta has been implementing digital literacy integrated learning. It entails four strategies. They are digital literacy through special programs, integrated learning materials, learning sources provision, and literacy through exemplary teachers and staff. The implementation of digital literacy has three benefits. Those are the aspects of use, protection, and prevention of students' deviant behavior. Deviant behavior can be avoided by preventing bully, avoiding harmful content access, and preventing cybercrime. In short, this study highlights the importance of creating innovative digital literacy methods based on the madrasa's needs and challenges. Moreover, because of the children's attachment to digital media and susceptibility to deviant behavior, sustainability literacy is necessary.

\section{REFERENCES}

Afwiyana, N. D. (2019). Langkah Cerdas Bermedia Sosial di Kalangan Santri Milenial. SAINTEKBU, 11(2), 39-44.

Anggeraini, Y., Faridi, A., Mujiyanto, J., \& Bharati, D. An. L. (2019). Literasi Digital : Dampak dan Tantangan dalam Pembelajaran Bahasa. Prosiding Seminar Nasional Pascasarjana (Prosnampas), Vol 2 No 1.

Astini, N. K. S. (2019, August). Pentingnya literasi teknologi informasi dan komunikasi bagi guru sekolah dasar untuk menyiapkan generasi milenial. In Prosiding Seminar Nasional Dharma Acarya (Vol. 1, No. 1).

APJI, T. (2020). Survei Pengguna Internet PJII 2019-Q2 2020, Ada kenaikan 25,5 Juta Pengguna Internet Baru di RI. November.

Atem. (2016). Ancaman Cyber Pornography terhadap Anak-Anak. Jurnal Moral Kemasyarakatan, Vol 2 No 1.

Butcher, N., Sarah, H., \& Moore, A. (2014). Harnessing OER to Develop Teachers: The Guyana Experience. Journal of Learning for Development, Vol 1 No 3.

Cohen, B. J. (2003). Theory and practice of psychiatry. Oxford University Press.

Dullas, A. R., Yncierto, K. D., Labiano, M. A., \& Marcelo, J. C. (2021). Determinants of a Variety of Deviant Behaviors: An Analysis of Family Satisfaction, Personality Traits, and Their Relationship to Deviant Behaviors Among Filipino Adolescents. Frontiers In Psychology.

Dvoryanchikov, N., Dozortseva, E., Delibalt, V., Natalia, B., Rubtsova, O., \& Bovina, I. 
(2020). Deviant Online Behavior In Adolescent And Youth Circles: In Search Of A Risk Assessment Model. International Journal of Cognitive Research in Science, Engineering and Education (IJCRSEE), Vol 8 No 2.

Echols, M. J., \& Shadily, H. (2013). Kamus Inggris Indonesia An English-Indonesia Dictionary. PT Gramedia.

Fardiah, D. (2021). Anticipating Social Media Effect: Digital Literacy among Indonesian Adolescents. International Journal of Multidisciplinary and Current Educational Research (IJMCER), Vol 3 No 3.

Fitriadi, H. (2013). Integrasi Teknologi Komunikasi dalam Pendidikan: Potensi Manfaat, Masyarakat berbasis Pengetahuan, Pendidikan Nilai, Strategi Implementasi dan Pengembangan Profesional. Jurnal Pendidikan Teknologi Dan Kejuruan, Vol 21 No.

Goode, E. (2016). Deviant Behavior (Edisi 11). Routlege.

Hendriani, W. (2017). Menumbuhkan Online Resilence pada Anak di Era Teknologi Digital. Prosiding Temu Ilmiah $X$.

Hendriani, W. (2018). Resiliensi Psikologis Sebuah Pengatar (Edisi Pert). Prenada Media Group.

Irianto, P. O., \& Febrianti, L. Y. (2017, June). Pentingnya penguasaan literasi bagi generasi muda dalam menghadapi MEA. In Proceedings Education and Language International Conference (Vol. 1, No. 1).

Jacobs, G., \& Castek, J. (2018). Digital problem solving: The literacies of navigating life in the digital age. Journal of Adolescent and Adult Literacy, Vol 61 No.

Jannah, M., Prasojo, L. D., \& Jerusalem, M. A. (2020). Elementary School Teachers' Perceptions of Digital Technology Based Learning in the 21st Century: Promoting Digital Technology as the Proponent Learning Tools. Al Ibtida: Jurnal PGMI, Vol 7 No 1 .

Kemp, S. W. A. S. (2020). Hootsuite (We are Social): Indonesian Digital Report 2020.

KPAI. (2020). Laporan Survey Nasional Komisi Perlindungan Anak Indonesia (KPAI).

Kurniawan, A. W., \& Eza, G. (2019). Evaluasi Capaian PISA 2018: Indonesia Perlu Segera Berbenah. Jurnal Vocational Education Policy White Paper, Vol 21 No.

Law, N., Woo, D., Torre, J. de la, \& Wong, G. (2018). No Title. UNESCO Institute for Statistics.

McGuinness, C., \& Fulton, C. (2019). Digital Literacy in Higher Education: A Case Study of Student Engagement with E-Tutorials Using Blended Learning. Journal of Information Technology Education: Innovations in Practice, Vol 18.

Mulyana. (2020). Pembelajaran Jarak Jauh Era Covid-19: Memperkuat Kompetensi Guru untuk Pembelajaran Efektif. Litbangdiklat Press.

Nanda, V. S., \& Budimansyah, D. (2020). Strengthening of Digital Media Literacy-Based Character Education on Hoax News Spreading to Students (Case Study on Citizenship Education Learning in SMP Negeri 2 Bandung). Journal of International Conference Proceeding, Vol 3 No 1.

Napitupulu, D. (2017). Kajian Peran Cyber law dalam Memperkuat Keamanan Sistem Informasi Nasional. Jurnal Kriminologi, Vol 1 No 1.

Olson, L., \& Stalbrant, E. E. (2008). Digital literacy as a challenge for Teacher Education 
Implications for educational frameworks and learning environments. IFIP World Computer Congress, TC 3, 11-18.

Przybylski, A., Mishkin, A., \& Et.al. (2014). A Shared Responsibility Building Childreen's Online Resilience. An Independent Research and Paper Commissioned, Supported by Virgin Madia and Parent Zone.

Rahman, N. A. ., Sairi, I. ., Zizi, N. A. ., \& Khalid, F. (2020). The Importance of Cybersecurity Education in School. International Journal of Information and Education Technology.

Spires, M., \& Bartlett, H. (2012). Digital Literacies and Learning : Designing a Path Forward. Friday Institute White Paper Series, No. 5(June), 1-24. www.fi.ncsu.edu/whitepapers

Subarkah, M. A. (2019). Pengaruh Gadget terhadap Perkembangan Anak. Jurnal Rausyan Fikr, Vol 15 No.

Sugiyono. (2011). Metode Penelitian Kuantitatif Kualitatif dan R\&D. Alfabeta.

Suleiman, M., \& Danmuchikwali, B. G. (2020). Digital Education: Opportunities, Threats, And Challenges. Jurnal Evaluasi Pendidikan, Vol 11 No.

Suroso. (2017). Kebijakan Kriminal Siber terhadap Anak; Tinjauan dalam Perspektif Hukum dan Pendidikan Moral. Program Magister Ilmu Hukum Universitas Diponegoro Semarang.

Syifa, L., \& Setianingsih, E. (2019). Dampak Penggunaan Gadget terhadap Perkembangan Psikologi pada Anak Sekolah Dasar. Jurnal iImiah Sekolah Dasar, Vol 3 No 4.

Triawang, G., \& Kuriniawan, E. (2021). The effect of digital literacy towards the selection of social science teacher learning media. Pegem Egitim ve Ogretim Dergisi, Vol 11 No.

Xie, X., \& Gai, X. (2019). A Meta-Analysis Of Media Literacy Interventions For Deviant Behaviors. Journal of Computers \& Education, Vol 139 No.

Yustika, G. P., \& Iswati, S. (2020). Digital Literacy in Formal Online Education: A Short Review. Dinamika Pendidikan, Vol 15 No. 